\title{
Structural evolution and strike-slip tectonics off north-western Sumatra
}

\author{
Kai Berglar $^{\mathrm{a},{ }^{*}}$, Christoph Gaedicke ${ }^{\mathrm{a}}$, Dieter Franke ${ }^{\mathrm{a}}$, Stefan Ladage $^{\mathrm{a}}$, Frauke Klingelhoefer ${ }^{\mathrm{b}}$ and Yusuf \\ S. Djajadihardja ${ }^{\mathrm{C}}$ \\ a Federal Institute for Geosciences and Natural Resources (BGR), Stilleweg 2, D-30655 Hanover, Germany
b Ifremer Centre de Brest, B.P. 70, 29280 Plouzané cedex, France
${ }^{c}$ Agency for the Assessment \& Application of Technology, Jl. M.H. Thamrin No.8, Jakarta 10340, Indonesia \\ *: Corresponding author : Kai Berglar, Tel.: +49 511643 2149; fax: +49 511643 3663, email address : \\ Kai.Berglar@bgr.de
}

\begin{abstract}
:
Based on new multi-channel seismic data, swath bathymetry, and sediment echosounder data we present a model for the interaction between strike-slip faulting and forearc basin evolution off northwestern Sumatra between $2^{\circ} \mathrm{N}$ and $7^{\circ} \mathrm{N}$. We examined seismic sequences and sea floor morphology of the Simeulue- and Aceh forearc basins and the adjacent outer arc high. We found that strike-slip faulting has controlled the forearc basin evolution since the Late Miocene. The Mentawai Fault Zone extends up to the north of Simeulue Island and was most probably connected farther northwards to the Sumatran Fault Zone until the end of the Miocene. Since then, this northern branch jumped westwards, initiating the West Andaman Fault in the Aceh area. The connection to the Mentawai Fault Zone is a left-hand step-over. In this transpressional setting the Tuba Ridge developed. We found a right-lateral strike-slip fault running from the conjunction of the West Andaman Fault and the Tuba Ridge in SSW-direction crossing the outer arc high. As a result, extrusion formed a marginal basin north of Simeulue Island which is tilted eastwards by uplift along a thrust fault in the west. The shift of strike-slip movement in the Aceh segment is accompanied by a relocation of the depocenter of the Aceh Basin to the northwest, forming one major Neogene unconformity. The Simeulue Basin bears two major Neogene unconformities, documenting that differences in subsidence evolution along the northern Sumatran margin are linked to both forearc-evolution related to subduction processes and to deformation along major strike-slip faults.
\end{abstract}

Keywords: Oblique subduction; Strike-slip; Forearc basin; Sumatra; Mentawai Fault Zone; West Andaman Fault 
1. Introduction

Oblique convergence of colliding plates is a common feature at convergent margins.

Partitioning of strain results in two major structural components: One that is perpendicular to the trench, represented by folds and thrusts in the accretionary prism, and a second component, accommodating the oblique convergence in strike-slip faults parallel to the trench (Beck et al., 1993; Beck, 1983; Fitch, 1972; Malod and Mustafa Kemal, 1996; McCaffrey, 1991). Examples of such strike-slip motions are the Liquine-Ofqui Fault (Cembrano et al., 1996) and Atacama Fault (Cembrano et al., 2005) in Chile or the Queen Charlotte/Fairweather fault system in Alaska (Doser and Lomas, 2000). Studying such major strike-slip systems is crucial to understand the evolution of oblique margins and their behavior in terms of forearc basin evolution.

The study area is located off north-western Sumatra between $2^{\circ} \mathrm{N}$ and $7^{\circ} \mathrm{N}$, covering the offshore region between the Mentawai Fault Zone and West Andaman Fault and the Sumatran Fault Zone (Fig. 1). Strong tectonic forces influence this area where the 2004 $M_{w}$ 9.0 Sumatra-Andaman and $2005 M_{w}$ 8.6 Nias Island earthquakes nucleated (Engdahl et al., 2007). The right-lateral offshore fault systems and the onshore Sumatran Fault Zone accommodate the trench-parallel component of the oblique convergence between the Indo-Australian and the Eurasian Plates (Diament et al., 1992; Malod and Mustafa Kemal, 1996; Samuel and Harbury, 1996; Sieh and Natawidjaja, 2000). The study area includes the Simeulue- and Aceh forearc basins and parts of the outer arc high. The studied basins show a change in water depth from about $1300 \mathrm{~m}$ in the Simeulue Basin to about $2800 \mathrm{~m}$ 
in the Aceh Basin and are clearly separated by an anticlinal structure that is elevated above the seafloor and referred to as Tuba Ridge by Malod et al. (1993).

The main purpose of this work is the assessment of the structural evolution of the strikeslip fault system and its relation to the forearc basin evolution off northern Sumatra based on the combined analysis of reflection seismic data, swath bathymetry and high resolution parametric echosounder data. The availability of a nearly complete swath bathymetric map in combination with a dense grid of seismic datasets of different resolutions allows us to address the questions of when strike-slip movements started and if these movements have had a notable influence on the evolution of the forearc basins. Our data make it possible to distinguish the interaction of the Mentawai Fault Zone and the West Andaman Fault in the Simeulue area which is not yet fully understood.

\section{Tectonic evolution of the western Sunda Arc}

Along the Sunda arc the oceanic Indo-Australian Plate subducts beneath the continental Eurasian Plate. The rate and direction of convergence of the Indo-Australian Plate with respect to the Eurasian Plate show a decreasing and slightly anticlockwise trend from southeast to northwest (Fig. 1). Based upon GPS measurements Prawirodirdjo and Bock (2004) proposed convergence rates of $61 \mathrm{~mm} / \mathrm{y}\left(\mathrm{N} 17^{\circ} \mathrm{E}\right)$ off the Sunda Strait and $51 \mathrm{~mm} / \mathrm{y}$ $\left(\mathrm{N} 11^{\circ} \mathrm{E}\right)$ off northern Sumatra. The plate motion model NUVEL-1A (DeMets et al., 1994) gives values of $70 \mathrm{~mm} / \mathrm{y}\left(\mathrm{N} 20^{\circ} \mathrm{E}\right)$ and $61 \mathrm{~mm} / \mathrm{y}\left(\mathrm{N} 15^{\circ} \mathrm{E}\right)$ respectively. A clockwise rotation of Sumatra and Malaya of about $20^{\circ}$ relative to Eurasia since the Late Miocene (Ninkovich, 1976; Nishimura et al., 1986) or Oligocene (Holcombe, 1977) was caused by the collision and indentation of India into Eurasia (Daly et al., 1991; Longley, 1997) and is the reason 
for a northward increasing obliquity of the subduction along the Sunda Arc. The curvature of the margin results in a plate convergence that gradually changes from nearly perpendicular subduction off Java to highly oblique subduction off northern Sumatra (Moore et al., 1980). Along the northwestern Sunda Arc strain partitioning and the development of arc-parallel strike-slip faults took place (Malod and Mustafa Kemal, 1996). The most prominent strike-slip shear zone is the Sumatran Fault Zone located on the Sumatran mainland along the volcanic arc (Bellon et al., 2004) which forms the Barisan Mountains (Fig. 1). The Sumatran Fault Zone accommodates most of the right-lateral strain of the relative plate motion and is proposed to have been active since the Mid Miocene (McCarthy and Elders, 1997). However, a distinct amount of arc-parallel strain is taken up by right-lateral strike-slip fault systems along the western edges of the forearc basins, namely the Mentawai Fault Zone and West Andaman Fault (Diament et al., 1992; Malod and Mustafa Kemal, 1996; McCaffrey, 1991). The Mentawai Fault Zone extends from the Sunda Strait in the south to at least the Island of Nias at about $1.5^{\circ} \mathrm{N}$ where it is probably connected with the Sumatran Fault Zone along the Batee Fault (Milsom et al., 1995). Likely the Mentawai Fault Zone extends farther north into the Simeulue Basin (Diament et al., 1992). The West Andaman Fault extends southwards from the Andaman Islands to the Simeulue Basin along the western border of the Aceh Basin (Curray, 2005). As pointed out by Curray et al. (1979) the Sumatran forearc acts as a sliver plate bounded to the west by the trench, below by the subducting plate, and to the east by the Sumatran Fault Zone. As a consequence the forearc sliver consists of elongated strips moving to the northwest. This was further refined by Malod and Kemal (1996) proposing two forearc microplates between the outer arc high and the Mentawai Fault Zone, separated by the Batee Fault. The western border of the northern microplate is represented by the West Andaman Fault. 
3. Methodology

133

134

135

We had approximately $2800 \mathrm{~km}$ of multi-channel seismic (MCS) data available in the study area from a total of more than $9700 \mathrm{~km}$ acquired during two research cruises with RV SONNE in 2006. Shot distance was $50 \mathrm{~m}$ and we used a digital 240-channel streamer of 3 $\mathrm{km}$ length with a receiver spacing of $12.5 \mathrm{~m}$, towed at a water depth of $6 \mathrm{~m}$. The acoustic signal was generated by a tuned G-gun array of 16 units comprising a total volume of 50.8 I operated at air pressure of $14.5 \mathrm{MPa}$. Data were recorded with a sampling interval of 2 $\mathrm{ms}$ and $14 \mathrm{~s}$ length. Stacking velocities were picked at regular intervals of $3 \mathrm{~km}$ along every line. Pre-stack processing included resampling to $4 \mathrm{~ms}$, trace editing, CMP-sort (nominal 30-fold coverage, 6.25 m spacing), Ormsby bandpass filter (6-12-60-160 Hz), polygon f-k filter (window of 60 traces and $1 \mathrm{~s}$ length), zerophase spiking deconvolution (52 ms operator length, $1 \mathrm{~s}$ design window beginning shortly below seabottom reflection), amplitude correction for spherical divergence based on stacking velocities $\left(1 /\left(t \times v^{\wedge} 2\right)\right)$, normal moveout correction (40\% stretch mute), and Radon velocity filter for multiple suppression (rejecting velocities differing more than $\pm 20 \%$ of corresponding stacking velocity). After stack we applied a space and time variant Ormsby bandpass filter (upper window: 10-20-60-100 Hz, lower window: 6-12-50-100 Hz), a minimum phase predictive deconvolution and a post-stack Kirchhoff time migration with $90 \%$ of stacking velocities.

Additionally, digitized scans converted to Segy-format from single-channel recordings acquired during the SUMENTA cruises in the early 90s (Izart et al., 1994; Malod et al., 1993; Malod and Mustafa Kemal, 1996) were available with a total length of about 4800 $\mathrm{km}$ in the study area. 
Together with the MCS data, high resolution parametric echosounder data (difference frequency of $3.5 \mathrm{kHz}$ ) were recorded with the ATLAS PARASOUND system at a sampling rate of $40 \mathrm{kHz}$. The data were resampled to $8 \mathrm{kHz}$, bandpass filtered (1.75-2.1-3.8-4 kHz) and the envelope seismic attribute applied for visualization.

The swath bathymetric data is a compilation of Japanese (Soh, 2006), British (Henstock et al., 2006; Tappin et al., 2007), French (Graindorge et al., 2008; Sibuet et al., 2007), American (RR0705, Cruise Report, 2007) and German (Ladage et al., 2006) datasets recorded in the area during several cruises. The bathymetric datasets were provided either in different native binary multibeam-system formats or as dumped grid data in xyz-ascii format. The data were used as delivered, i.e. no further editing was performed, and merged using the MB-System software package (Caress and Chayes, 1996). For gridding, the different surveys were given priorities by a weighting scheme based on aerial coverage and data quality to minimize artifacts and inconsistencies in regions of overlap. Gridding was performed with a grid spacing of $100 \mathrm{~m}$ and maps plotted with the GMT software package (Wessel and Smith, 1991).

\section{Structural Analysis}

The evaluated area off northern Sumatra covers three basin domains: The Aceh Basin, the Simeulue Basin and a smaller basin located northwest of Simeulue Island. For clarity, we introduce the name Tuba Basin for this depression (Fig. 1).

A morphological analysis of the seafloor based on bathymetric data was carried out to identify tectonic structures. 2-D MCS data were used to determine the type and time of 
activity of the structures. We used simultaneously recorded high-resolution echosounder data to verify if such structures affected the uppermost sedimentary layers thus indicating recent activity.

\subsection{Aceh Basin}

The Aceh Basin is the northernmost forearc basin off Sumatra and is located in the conjunction between the West Andaman Fault and the Sumatran Fault Zone. It has a northward narrowing triangular shape covering an area of about $6600 \mathrm{~km}^{\wedge} 2$ with the northern tip reaching up to the island of Greater Nicobar (Fig. 1). From there, the basin spans southward for about $260 \mathrm{~km}$ where it is bordered by the Tuba Ridge (Fig. 1; Mosher et al., 2008). In E-W direction the basin has a width from the West Andaman Fault to the inner slope of about $65 \mathrm{~km}$. To the east, the inner slope leads over to the Sumatran mainland and, offshore the northern tip of Sumatra, the Sumatran Fault Zone. The basin is filled with well stratified sedimentary sequences of an average thickness of 2 s two-way traveltime (TWT) that increases southwards. The architecture of the Aceh Basin is quite uniform in the south, while it becomes complex in the north.

The western border of the Aceh Basin is coincident with the West Andaman Fault. Bathymetry (Fig. 2A) shows a NNW-SSE-striking, mainly linear feature with a well defined main fault and several subordinate fault lines imaged as anticlines. These branch off into both the forearc basin and the outer arc high. The inset in Fig. 3 shows the typical expression of the main fault line of the West Andaman Fault along the Aceh Basin, a small depression filled syntectonically with westward dipping sediments, described in detail by Seeber et al. (2007). It is enframed at both sides by anticlines of about $6 \mathrm{~km}$ in width. The easternmost anticline is built up by the entire Neogene sedimentary column of the Aceh 
Basin. The deformation affected the youngest sediments indicating a recent activity of the West Andaman Fault, also evidenced by fault plane solutions (Kamesh Raju et al., 2007).

In the entire basin the base of the well stratified sediments is formed by a distinct unconformity (Figs. 3, 4 and 5). This unconformity is of regional extent and was probably caused by uplift and subsequent erosion of the forearc area off Sumatra. It was interpreted in all forearc basins along the Sumatran trench as of Oligocene/Early Miocene age (Beaudry and Moore, 1985; Izart et al., 1994; Karig et al., 1979; Karig et al., 1980; Malod et al., 1993; Rose, 1983; Schlüter et al., 2002; Susilohadi et al., 2005; van der Werff, 1996). From this widespread extent and the narrow position to the Simeulue Basin where the age is proved by drilling we propose that the basal unconformity in the Aceh Basin is also of base Neogene age. On top of the basal unconformity two well layered sedimentary sequences are divided by an angular unconformity. Sequence A has a maximum thickness of $4 \mathrm{~s}$ (TWT) in the southern Aceh Basin near the Tuba Ridge (Fig. 5). Farther north, it thins to $1.4 \mathrm{~s}$ (TWT) and is trenchward rotated (Fig. 3). Sequence B is horizontally layered and onlaps the unconformity below. The main depocenter of sequence B is located in the central Aceh Basin (Fig. 3) with a maximum thickness of about $1.3 \mathrm{~s}$ (TWT). The whole depocenter of the Aceh Basin shows a northward migrating trend of subsidence over time.

Fig. 6 A spans over $120 \mathrm{~km}$ from the West Andaman Fault to the Sumatran Fault Zone and covers the northern part of the Aceh Basin and the area adjacent to the east. Again, the main line of the West Andaman Fault is developed as a narrow synsedimentary filled depression $(\mathrm{km} \mathrm{7})$. The deformed area at the transition to the forearc basin is composed of uplifted and deformed sediments. The narrow depocenter contains two sedimentary sequences above the acoustic basement ( $\mathrm{km} \mathrm{17-33).} \mathrm{The} \mathrm{lower} \mathrm{one} \mathrm{is} \mathrm{confined} \mathrm{to} \mathrm{the}$ eastern part of the basin ( $\mathrm{km} \mathrm{25-33)} \mathrm{and} \mathrm{is} \mathrm{subdivided} \mathrm{into} \mathrm{two} \mathrm{subsections.} \mathrm{Sub-parallel}$ 
reflectors dominate in the basal section. The upper section contains westward dipping reflectors, downlapping on the sediments below. The upper sequence of the basin is well layered and downlaps onto the lower sequence in the east. Here, this sequence shows a divergent reflection pattern, indicating a deposition syntectonically to subsidence $(\mathrm{km} 25$ 30).

In the area between the Aceh Basin and the Sumatran Fault Zone to the east an erosional truncation separates deformed sediments from a package with sub-parallel configuration atop. The internal configuration of the sediments below the erosional truncation points to a deposition in a basin setting and we refer to this area as Paleo Aceh Basin. Incisions of a channel (see Fig. 1) are visible on the profile shown in Fig. 6A from km 50-58. Below these incisions an older sedimentary basin is imaged (km 40-60). It contains two major sedimentary sequences with the upper onlapping on the lower one and is bounded to the east by an extensional fault ( $\mathrm{km} \mathrm{59).} \mathrm{A} \mathrm{distinguishing} \mathrm{of} \mathrm{the} \mathrm{individual} \mathrm{sedimentary}$ sequences was impossible with the data at hand. The sedimentary fill might either be interpreted as consisting of only sequence B (similar the northern Aceh Basin) or as sequences A and early B (similar the southern Aceh Basin). We tentatively interpret the erosional truncation as separating sequence $A$ from early sequence $B$ because of the distinct onlapping reflection pattern also found in the southern Aceh Basin and because we observe a general westwards migration of the western border of the northern Aceh Basin.

Further eastwards sediments below the erosional truncation are strongly folded. Folding can be followed on seismic sections (Fig. 6B) on a line across the area east of the Aceh Basin in southern direction to the eastern edge of the Tuba Ridge. We interpret a nonactive strike-slip fault similar to the Sumatran Fault Zone and West Andaman Fault. 


\subsection{Tuba Basin}

The Tuba Basin is a narrow depression to the south of the Aceh Basin. It is separated from the latter by the Tuba Ridge, a zone of compressional uplift. Fig. 5 shows the large anticline of the Tuba Ridge from km 58-75 uplifting the basin sediments for more than 700 $\mathrm{m}$ to the south and $1000 \mathrm{~m}$ to the north over the surrounding ocean floor. The Tuba Basin is trench-parallel elongated, and extends over $160 \mathrm{~km}$ in NW-SE direction with a maximum width of about $70 \mathrm{~km}$, totaling in an area of about $6000 \mathrm{~km}^{\wedge} 2$. To the west it is confined by the outer arc high which is cut by a right-lateral strike-slip fault running from the western end of the Tuba Ridge in SSW-direction (Fig. 2B). The northern part of the basin is occupied by a depression covering an area of approximately $1200 \mathrm{~km}^{\wedge} 2$ with side lengths of about $27 \mathrm{~km}$ and $50 \mathrm{~km}$. Here, the seafloor is at a maximum water depth of about 2200 $\mathrm{m}$ whereas it reaches depths of $1700 \mathrm{~m}$ in the southerly located area. The sedimentary infill is generally thin with a maximum thickness of about $1.2 \mathrm{~s}$ (TWT; Fig. 7). The northern depression is bounded to the south by normal faults and crossed by a W-E striking escarpment of about $80 \mathrm{~m}$ (Figs. 2B and 5, km 83 and inset). Most likely this part of the Tuba Basin was disconnected from the Aceh Basin by the formation of the Tuba Ridge because reflectors of sequence $A$, though heavily folded and dragged, can be followed through the Tuba Ridge into the northern Tuba Basin (Fig. 5).

\section{Bathymetry of the southern basin part (Fig. 2C) shows a steady northwest-directed} inclination with a slope angle of about $1.4^{\circ}$ (Fig. 7) from the outer arc high in the west to the eastern boundary of the basin where the recent depocenter is located (Figs. 7, km 4555 and $8, \mathrm{~km} \mathrm{32-40).} \mathrm{Tilting} \mathrm{of} \mathrm{the} \mathrm{basin} \mathrm{is} \mathrm{documented} \mathrm{by} \mathrm{a} \mathrm{circular} \mathrm{buildup} \mathrm{structure} \mathrm{on}$ the ocean floor (Figs. 2C and 8, km 15-20) which exhibits the same inclination. Several folds with a NW-SE strike are distinct in the bathymetric map, the most prominent at the 
border to the outer arc high (Fig 2C). The seismic image shows a steep high-amplitude reflector band below this fold (Fig 7, km 6-12) which we interpret as a thrust fault. Uplift along this fault may have resulted in a tilting of the western part of the Tuba Basin and subsequent compressive deformation of the sedimentary succession in the basin (Fig. 5, km 125-132; Fig. 7, km 22-55; Fig. 8, km 25-40). The reflection pattern of the sequences and basement of the Tuba Basin differ from the other forearc basins and are merely typical for the outer arc high.

\subsection{Simeulue Basin}

\section{With an area of about 15,000 $\mathrm{km}^{\wedge} 2$, the Simeulue Basin is the largest forearc basin off} northern Sumatra. It is a northward narrowing, trench-parallel elongated depression and extends over $260 \mathrm{~km}$ in NW-SE direction and approximately $100 \mathrm{~km}$ in SW-NE direction. The maximum water depth is about $1300 \mathrm{~m}$ (Berglar et al., 2008). The basin contains a sedimentary succession of Early Miocene to recent age (Beaudry and Moore, 1985; Berglar et al., 2008; Karig et al., 1979; Rose, 1983) of up to $5 \mathrm{~s}$ (TWT). It is bounded to the south by the Banyak Islands and to the west by Simeulue Island and a ridge-like structure separating it from the Tuba Basin. To the east a well defined slope and shelf passes into the Sumatran mainland.

The stratigraphy and subsidence of the Simeulue Basin was described in detail by Berglar et al. (2008): The base of the stratified sediments is formed by the regional basal Neogene unconformity. Atop, three major stages of subsidence and deposition were identified. Subsidence in the Simeulue Basin was initiated during the Early and Middle Miocene in the western part of the basin where half grabens formed. A second major stage took place during the Late Miocene and Pliocene when the accretionary wedge west of the basin 
consolidated and formed the distinct outer arc high. This resulted in a consistently subsiding trough along the western border of the basin and a broad shelf in the eastern part. The last phase of the second stage was characterized by a westward shift of the depocenter probably associated with the initiation of strike-slip faulting. The Pleistocene to recent stage shows relatively uniform subsidence across the basin except for the central part where uplift and subsequent normal faulting at the crests of the uplifted areas occurred.

The Simeulue Basin is characterized by two styles of deformation, namely large anticlines with normal faulting at the crest and strike-slip related faulting and folding. Fig. 9 (km 108128) shows an example of an anticline with subsequent normal faulting. The faults penetrate from the ocean floor down to Early Miocene sediments on top of an anticline of about $70 \mathrm{~km}$ in width. The crest is subject to erosion exposing Pliocene sediments. The deep reaching normal faults and the size of the anticline suggest uplift of the basement. Bathymetry (Fig. 2D) reveals the surficial shape of the anticline as semicircular in northeastern direction towards the basin, pointing to either a NE-dipping crest line or a dome-like architecture of this area of uplift. The SW-NE strike of the normal faults follow the axis of the anticline (Fig. 2D).

An example of strike-slip related faulting and folding is the elongated structure of NW-SE strike separating the Simeulue- and Tuba Basins north of Simeulue Island (Fig. 2C).

Seismic sections (Figs. 8, km 48-63 and 9, km 0-20) depict a positive flower structure of about $15 \mathrm{~km}$ in width and $800 \mathrm{~m}$ in height. We interpret this structure as the main line of the transpressional fault continuing the Mentawai Fault Zone north of the Banyak Islands up to the east of the Tuba Ridge. The deformation extends farther into the Simeulue Basin as documented by blind reverse faults deforming the basin sediments (Fig. 8, km 70-80). 
Fig. 2D shows a large channel circuiting a fold; similar anticlines are located to the NW as well as on Simeulue Island.

The transition from the outer arc high south of Simeulue Island into the southwestern basin part is illustrated on Figs. 2E and 10. There, a series of wrench faults is observed. Interfingering sedimentary packages (Fig. 10, km 15-20) depict the alternating intensity of deformation and uplift of wrench faults that resulted in changing direction of sediment supply into the basin. The northeastern wrench fault on Fig. 10 (km 25-30) exhibits onlapping reflectors with upwards decreasing angles marking the initiation of deformation in Late Miocene to Pliocene time. The recent activity of this fault is revealed by uplift and erosion of youngest sediments imaged in subbottom profiler data (inset).

\section{Discussion}

\section{An earlier interpretation based on single-channel seismic data proposed a common} stratigraphy for the entire forearc basin region off northern Sumatra (Izart et al., 1994). These authors correlated sedimentary sequences from the Nias Basin, previously described by Beaudry and Moore (1981) and Matson and Moore (1992) in the south to the Aceh Basin in the north. However, we propose that the basin evolution differs significantly from south to north.

The stratigraphic framework of the Simeulue Basin established by Berglar et al. (2008) was calibrated with published data of exploration wells (Beaudry and Moore, 1985; Karig et al., 1979; Rose, 1983) and the temporal delimitation of identified tectonic structures is well constrained. The Simeulue Basin evolved in three major stages. To distinguish in 
detail the sedimentary sequences in the Aceh Basin, we reviewed the old seismic data and combined them with our newly acquired MCS data. In contrast to the Simeulue Basin we found only two main stages. Independently from the stratigraphic position of the sedimentary fill in the Aceh Basin, this is a clear indication of the different evolution of the forearc basins. The evolution of the forearc basins is apparently much more complex than previously assumed.

The main depocenter of sequence A is located in the southern Aceh Basin. Recently, this part was subject to uplift and folding, as documented by exposure and subsequent erosion of sequence A (Fig. 5). Since this uplift, the depocenter moved considerably northwards while the southern part is sediment-starved. The age of unconformity $A / B$ in the Aceh Basin is not determinable without doubt by sequence stratigraphy. It may be either of Mid Miocene age, as the oldest major Neogene unconformity in the Simeulue Basin, or considerably younger.

Strike-slip movements are a direct consequence of the oblique convergence of colliding plates and thus are of regional extent. We propose that these strike-slip movements in the forearc basins off Sumatra can be used to tie the evolution scenarios for the basins. In the Simeulue Basin the initiation of strike-slip movement started earliest in the Late Miocene (Fig. 10; Berglar et al., 2008). In the Aceh Basin sequence B can clearly be associated with the initiation of strike-slip movement along the West Andaman Fault. Here, strike-slip faulting replaced a former, now inactive fault, as e.g. imaged on Fig. 6A (km 70-80) and the depocenter of the northern Aceh Basin probably migrated westward over time. If our assumption is right, the unconformity between sequence $A$ and $B$ in the Aceh Basin then would approximately be at the Miocene/Pliocene boundary. The onset of movements along the West Andaman Fault thus resulted in a significant north- and westward shift of 
391 the depocenter in the Aceh Basin and is an ongoing process (Seeber et al., 2007).

392 Extensional faulting (Fig. 6A, km 33 and 59) at the eastern edges of the narrow half 393 graben like depocenters and the westward dip of sequence A (Fig. 3) may be explained by 394 the slightly curved geometry of the West Andaman Fault resulting in a releasing bend.

395

The two major forearc basins in the study area, namely the Simeulue- and the Aceh Basins, thus evolved step by step. While subsidence continued in the Aceh Basin (sequence A) a major Mid/Late Miocene unconformity in the Simeulue Basin marks differences in basin evolution. With the initiation of strike-slip faulting, subsidence expanded considerably eastwards in the Simeulue Basin, but the Mentawai Fault Zone itself affected only the westernmost part of the basin. In contrast, the sediments of the northern Aceh Basin were deformed by the northward continuation of the Mentawai Fault Zone. The cessation of this northermost fault section (Fig. 11) and subsequent jump of strike-slip movement initiated the West Andaman Fault. The Aceh Basin adapted to the structural reorganization by erosion of the Paleo Aceh Basin and a shift of the depocenter to the west and north to the recent position.

The complex evolution of the Simeulue Basin is also documented in the interaction of two different styles of deformation: (1) Uplift and subsequent erosion accompanied by deep reaching normal faults, and (2) strike-slip faulting and folding along the western border of the basin.

(1) Uplift and basin inversion starting in the Pleistocene is probably related to reactivation of lower Miocene half graben structures responsible for the initial Neogene subsidence of the basin (Berglar et al., 2008). The recent activity is proven by bathymetric steps with SW-NE strike caused by the normal faults at the crest of the anticlines (Fig. 2D). Two 
bottom simulating reflectors (Fig. 9, km 115-123) may indicate a rapid recent uplift, where the gas hydrates did not had time to adjust to the changes of the gas hydrate stability zone (Foucher, 2002; Popescu et al., 2006; Posewang and Mienert, 1999). The deep reaching normal faults visible on seismic sections (Fig. 9) are caused by recent local uplift of Neogene or even deeper structures at the edge of the basin close to Simeulue Island, possibly due to tilting of Early/Mid Miocene basement blocks as described by Berglar et al. (2008). It can be speculated that this reactivation of block rotation may be related to changes in dip of the subducting oceanic crust directly below (Franke et al., 2008) or to local changes in plate coupling resulting in inhomogeneous compensation of tectonic slip (Ammon, 2006; Ammon et al., 2005; Briggs et al., 2006).

(2) Strike-slip deformation led to primary faulting along the main fault line and secondary folding to both sides of the main fault. The main fault line along the western boundary of the Simeulue Basin is imaged on Figs. 2D, 8 and 9. As the location and trend at the western rim of the forearc basin is similar to that of the Mentawai Fault Zone in the southerly located Bengkulu Basin (Diament et al., 1992) we attribute the strike-slip fault in the Simeulue Basin to this system. The secondary folds are sigmoidal shaped, with their axis more or less parallel to the main fault line and lengths of about 10-20 km (Figs. 2C-E, 9 and 10). These are the surficial expression of wrench faults typically found along the Sumatran forearc basins (Diament et al., 1992). Fig. 9 shows several structures related to wrench faulting. $\mathrm{Km} \mathrm{58-70} \mathrm{is} \mathrm{occupied} \mathrm{by} \mathrm{an} \mathrm{area} \mathrm{of} \mathrm{local} \mathrm{uplift.} \mathrm{As} \mathrm{revealed} \mathrm{by} \mathrm{the}$ bathymetric data (Fig. 2D), this is an anticline which is cut along strike by the seismic section. It has a visible length of about $12 \mathrm{~km}$ on the surface and a sigmoidal shaped hinge line. Directly south of this anticline onshore topography depicts a similar shaped structure on Simeulue Island, but with a mirrored form. The striking similarity of both structures led 
us to interpret the position of the trend of the main Mentawai fault line between these folds, along the eastern shelf off Simeulue Island.

The Mentawai Fault Zone is connected to the West Andaman Fault by the Tuba Ridge (Figs. 2B and 5). In our view the Tuba Ridge is a transpressional uplifted area of a lefthand step-over in the right-lateral strike-slip system, showing typical secondary folding to the north (Fig. 2B; Fig. 5, km 40-50). A second, SSE-trending right-lateral strike-slip fault meets the West Andaman Fault at its southernmost tip at the transition to the Tuba Ridge (Fig. 11), similarly described by Seeber et al. (2007). This fault is traceable on bathymetry data across the entire outer arc high and accretionary prism to the Sumatra Trench. In this regime the northern Tuba Basin to the south of the Tuba Ridge extruded in southward direction leading to deeply seated extensional normal faults evident in our seismic data (Fig. 5, km 75-100). Overlying sediments are recently affected and the uppermost strata are torn (Figs. 2B and 5, inset). A thrust fault bordering the southern Tuba Basin to the west (Figs. 2C, 7 and 8) gives evidence for recent compression and tilting in that part of the basin. The Tuba Basin is bordered in landward direction by ridges which act as barriers hindering sediments to enter the basin making determination of timing of deformation difficult. Because even the uppermost strata were subject of thrusting and folding (Fig. 5, km 125-132; Fig. 7, km 22-55; Fig. 8, km 25-40) we speculate that the thrust fault and minor reverse faults within the basin are active.

\section{Conclusion}

From these findings we conclude the following evolution scenario for the strike-slip systems and the forearc basins off NW Sumatra: Since their initiation in the Late Miocene 
strike-slip faults have controled the forearc basin evolution off northern Sumatra. The northern branch of the Mentawai Fault Zone is traceable along the western boundary of the Simeulue Basin. Until the Miocene/Pliocene boundary the Mentawai Fault Zone was most probably connected to the Sumatran Fault Zone. Until that time the depocenter of the northern Aceh Basin was located further eastwards. In the Lower Pliocene the Aceh section of the Mentawai Fault Zone jumped westward or left-hand to the position of the West Andaman Fault. The shift of the fault was accompanied by a west- and northward shift of the depocenter in the Aceh Basin. The Tuba Ridge is a result of compression at this left-hand step-over. This ridge and the Mentawai Fault Zone isolate the Tuba Basin from terrigenous sediment sources leading to its recent sediment starved setting. A NNESSW trending right-lateral strike-slip fault cuts from the Sumatra Trench through the accretionary prism and outer arc high. Interaction of this fault with the West Andaman Fault leads to subsidence and extrusion of the northern Tuba Basin, the southern Tuba Basin is tilted and compressed by uplift along a thrust fault. Initiation of strike-slip movement in the Simeulue Basin is accompanied by an expansion of subsidence for several kilometers in the direction of Sumatra. Recent inversion is observed in the Simeulue Basin which we attribute either to change in dip of the oceanic crust or to changes in coupling of the upper and lower plates.

\section{Acknowledgements}

The authors express their gratitude to all colleagues making this work possible by organizing the projects and by collecting and processing the data. In particular we thank the ship's masters Lutz Mallon and Oliver Meyer and the crews of RV SONNE for their cooperation and support during the SeaCause and SUMATRA cruises. Also to mention 
are Gregory Moore and Nano Seeber for their helpful and constructive reviews. We are grateful to The Agency for the Assessment and Application of Technology (BPPT) and Indonesian Government for their support and permission for the scientific investigation in Indonesian waters. We thank Ingo Heyde and Ewald Lüschen for their helpful notes on magnetic anomalies and seismic processing, respectively. We appreciate Michael Schnabel for corrections and suggestions on the manuscript. The research projects were carried out with grants 03G0186A (SeaCause) and 03G0189A (SUMATRA) of the Federal Ministry of Education and Research (BMBF), Germany.

References

Ammon, C.J., 2006. Megathrust investigations. Nature 440(7080), 31-32. doi: 10.1038/440031a.

Ammon, C.J., Ji, C., Thio, H.K., Robinson, D., Ni, S., Hjorleifsdottir, V., Kanamori, H., Lay, T., Das, S., Helmberger, D., Ichinose, G., Polet, J., Wald, D., 2005. Rupture Process of the 2004 Sumatra-Andaman Earthquake. Science 308(5725), 1133-1139. doi: 10.1126/science.1112260.

Beaudry, D., Moore, G.F., 1981. Seismic-stratigraphic framework of the forearc basin off central Sumatra, Sunda Arc. Earth and Planetary Science Letters 54(1), 17-28. doi: 10.1016/0012-821X(81)90065-0.

Beaudry, D., Moore, G.F., 1985. Seismic stratigraphy and Cenozoic evolution of West Sumatra forearc basin. The American Association of Petroleum Geologists Bulletin 69(5), 742-759. 
Beck, M.E., Rojas, C., Cembrano, J., 1993. On the nature of buttressing in margin-parallel strike-slip fault systems. Geology 21(8), 755-758. doi: 10.1130/00917613(1993)021<0755:OTNOBI>2.3.CO;2.

Beck, M.E., 1983. On the mechanism of tectonic transport in zones of oblique subduction. Tectonophysics 93(1-2), 1-11. doi: 10.1016/0040-1951(83)90230-5.

Bellon, H., Maury, R.C., Sutanto, Soeria-Atmadja, R., Cotten, J., Polve, M., 2004. 65 m.y.long magmatic activity in Sumatra (Indonesia), from Paleocene to Present. Bulletin de la Societe Geologique de France 175(1), 61-72. doi: 10.2113/175.1.61.

Berglar, K., Gaedicke, C., Lutz, R., Franke, D., Djajadihardja, Y.S., 2008. Neogene subsidence and stratigraphy of the Simeulue forearc basin, Northwest Sumatra. Marine Geology 253(1-2), 1-13. doi: 10.1016/j.margeo.2008.04.006.

Briggs, R.W., Sieh, K., Meltzner, A.J., Natawidjaja, D., Galetzka, J., Suwargadi, B., Hsu, Y.j., Simons, M., Hananto, N., Suprihanto, I., Prayudi, D., Avouac, J.P., Prawirodirdjo, L., Bock, Y., 2006. Deformation and Slip Along the Sunda Megathrust in the Great 2005 Nias-Simeulue Earthquake. Science 311(5769), 1897-1901. doi: 10.1126/science.1122602.

Caress, D., Chayes, D., 1996. Improved processing of Hydrosweep DS multibeam data on the R/V Maurice Ewing. Marine Geophysical Researches 18, 631-650. doi: 10.1007/BF00313878.

Cembrano, J., González, G., Arancibia, G., Ahumada, I., Olivares, V., Herrera, V., 2005. Fault zone development and strain partitioning in an extensional strike-slip duplex: A case study from the Mesozoic Atacama fault system, Northern Chile. Tectonophysics 400(1-4), 105-125. doi: 10.1016/j.tecto.2005.02.012.

Cembrano, J., Herve, F., Lavenu, A., 1996. The Liquine Ofqui fault zone: a long-lived intraarc fault system in southern Chile. Tectonophysics 259(1-3), 55-66. doi: 10.1016/00401951(95)00066-6. 
Curray, J.R., Moore, D.G., Lawver, L.A., Emmel, F.J., Raitt, R.W., Henry, M., Kieckhefer, R., 1979. Tectonics of the Andaman Sea and Burma. In: J.S. Watkins, L. Montadert, P.W. Dickerson (Eds.), Geological and geophysical investigations of continental margins. Memoir, vol. 29, American Association of Petroleum Geologists, Tulsa, OK, pp. 189-198.

Curray, J.R., 2005. Tectonics and history of the Andaman Sea region. Journal of Asian Earth Sciences 25(1), 187-232. doi: 10.1016/j.jseaes.2004.09.001.

Daly, M., Cooper, M., Wilson, I., Smith, D., Hooper, B., 1991. Cenozoic plate tectonics and basin evolution in Indonesia. Marine and Petroleum Geology 8(1), 2-21. doi: 10.1016/0264-8172(91)90041-X.

DeMets, C., Gordon, R.G., Argus, D.F., Stein, S., 1994. Effect of recent revisions to the geomagnetic reversal time scale on estimates of current plate motions. Geophysical Research Letters 21(20), 2191-2194. doi: 10.1029/94GL02118.

Deplus, C., Diament, M., Hebert, H., Bertrand, G., Dominguez, S., Dubois, J., Malod, J., Patriat, P., Pontoise, B., Sibilla, J.J., 1998. Direct evidence of active deformation in the eastern Indian oceanic plate. Geology 26(2), 131-134. doi: 10.1130/00917613(1998)026<0131:DEOADI>2.3.CO;2.

Diament, M., Harjono, H., Karta, K., Deplus, C., Dahrin, D., Zen, M. T., J., Gerard, M., Lassal, O., Martin, A., Malod, J., 1992. Mentawai fault zone off Sumatra: A new key to the geodynamics of western Indonesia. Geology 20(3), 259-262. doi: 10.1130/00917613(1992)020<0259:MFZOSA>2.3.CO;2.

Doser, D.I., Lomas, R., 2000. The transition from strike-slip to oblique subduction in Southeastern Alaska from seismological studies. Tectonophysics 316(1-2), 45-65. doi: 10.1016/S0040-1951(99)00254-1.

Engdahl, E. R., Villasenor, A., DeShon, H. R., and Thurber, C. H., 2007, Teleseismic Relocation and Assessment of Seismicity (1918-2005) in the Region of the $2004 \mathrm{Mw}$ 
9.0 Sumatra-Andaman and 2005 Mw 8.6 Nias Island Great Earthquakes. Bulletin of the Seismological Society of America 97, S43-61, doi: 10.1785/0120050614.

Fitch, T.J., 1972. Plate Convergence, Transcurrent Faults, and Internal Deformation Adjacent to Southeast Asia and the Western Pacific. Journal of Geophysical Research 77(23), 4432-4460. doi: 10.1029/JB077i023p04432.

Foucher, J.P., 2002. Observation and tentative interpretation of a double BSR on the Nankai Slope. Marine Geology 187(1-2), 161-175. doi: 10.1016/S00253227(02)00264-5.

Franke, D., Schnabel, M., Ladage, S., Tappin, D.R., Neben, S., Djajadihardja, Y.S., Muller, C., Kopp, H., Gaedicke, C., 2008. The great Sumatra-Andaman earthquakes - Imaging the boundary between the ruptures of the great 2004 and 2005 earthquakes. Earth and Planetary Science Letters 269(1-2), 118-130. doi: 10.1016/j.epsl.2008.01.047.

Graindorge, D., Klingelhoefer, F., Sibuet, J.C., McNeill, L., Henstock, T.J., Dean, S., Gutscher, M.A., Dessa, J.X., Permana, H., Singh, S.C., Leau, H., White, N., Carton, H., Malod, J.A., Rangin, C., Aryawan, K.G., Chaubey, A.K., Chauhan, A., Galih, D.R., Greenroyd, C.J., Laesanpura, A., Prihantono, J., Royle, G., Shankar, U., 2008. Impact of the lower plate on upper plate deformation at the NW Sumatran convergent margin from seafloor morphology. Earth and Planetary Science Letters (In Press). doi: 10.1016/j.epsl.2008.04.053.

Henstock, T.J., McNeill, L.C., Tappin, D.R., 2006. Seafloor morphology of the Sumatran subduction zone: Surface rupture during megathrust earthquakes? Geology 34(6), 485-488. doi: 10.1130/22426.1.

Holcombe, C.J., 1977. Earthquake foci distribution in the Sunda Arc and the rotation of the backarc area. Tectonophysics 43(3-4), 169-180. doi: 10.1016/0040-1951(77)90115-9. 
Izart, A., Mustafa Kemal, B., Malod, J.A., 1994. Seismic stratigraphy and subsidence evolution of the Northwest Sumatra fore-arc basin. Marine Geology 122(1-2), 109-124. doi: 10.1016/0025-3227(94)90207-0.

Kamesh Raju, K.A., Murty, G.P.S., Amarnath, D., Kumar, M.L.M., 2007. The West Andaman Fault and its influence on the the aftershock pattern of the recent megathrust earthquakes in the Andaman-Sumatra region. Geophysical Research Letters 34(3), L03305. doi: 10.1029/2006GL028730.

Karig, D.E., Suparka, S., Moore, G.F., Hehanussa, P.E., 1979. Structure and Cenozoic evolution of the Sunda Arc in the central Sumatra region. In: J.S. Watkins, L. Montadert, P.W. Dickerson (Eds.), Geological and geophysical investigations of continental margins. Memoir, vol. 29, American Association of Petroleum Geologists, Tulsa, OK, pp. 223-237.

Karig, D.E., Lawrence, M.B., Moore, G.F., Curray, J.R., 1980. Morphology and shallow structure of the lower trench slope off Nias Island, Sunda Arc. In: D.E. Hayes (Ed.), The tectonic and geologic evolution of Southeast Asian seas and islands. Geophysical Monograph, vol. 23, American Geophysical Union, Washington, DC, pp. 179-208.

Ladage, S., Weinrebe, W., Gaedicke, C., Barckhausen, U., Flueh, E.R., Heyde, I., Krabbenhoeft, A., Kopp, H., Fajar, S., Djajadihardja, Y., 2006. Bathymetric Survey Images Structure off Sumatra. Eos, Transactions American Geophysical Union 87(17), 165-172. doi: 10.1029/2006EO170001.

Longley, I.M., 1997. The tectonostratigraphic evolution of SE Asia. In: A.J. Fraser, S.J. Matthews, R.W. Murphy (Eds.), Petroleum Geology of Southeast Asia. Special Publications, vol. 126, Geological Society, London, pp. 311-339. doi: 10.1144/GSL.SP.1997.126.01.19.

Malod, J.A., Mustafa Kemal, B., Beslier, M.O., Deplus, C., Diament, M., Karta, K., Mauffret, A., Patriat, P., Pubellier, M., Regnault, H., Aritonang, P., Zen, M. T., J., 1993. 
Deformations du bassin d'avant-are au nord-ouest de Sumatra: une reponse a la subduction oblique. Comptes Rendus de l'Academie des Sciences de Paris, Série 2 316(6), 791-797.

Malod, J.A., Mustafa Kemal, B., 1996. The Sumatra Margin: oblique subduction and lateral displacement of the accretionary prism. In: R. Hall, D. Blundell (Eds.), Tectonic Evolution of Southeast Asia. Special Publications, vol. 106, Geological Society, London, pp. 19-28. doi: 10.1144/GSL.SP.1996.106.01.03.

Matson, R.G., Moore, G.F., 1992. Structural influences on Neogene subsidence in the central Sumatra fore-arc basin. In: J.S. Watkins, F. Zhiqiang, K.J. McMillen (Eds.), Geology and geophysics of continental margins. Memoir, vol. 53, American Association of Petroleum Geologists, Tulsa, OK, United States, pp. 157-181.

McCaffrey, R., 1991. Slip vectors and stretching of the Sumatran fore arc. Geology 19(9), 881-884. doi: 10.1130/0091-7613(1991)019<0881:SVASOT>2.3.CO;2.

McCarthy, A.J., Elders, C.F., 1997. Cenozoic deformation in Sumatra: oblique subduction and the development of the Sumatran fault system. In: A.J. Fraser, S.J. Matthews, R.W. Murphy (Eds.), Petroleum Geology of Southeast Asia. Special Publications, vol. 126, Geological Society, London, pp. 355-363. doi: 10.1144/GSL.SP.1997.126.01.21. Milsom, J., Sain, B., Sipahutar, J., 1995. Basin formation in the Nias area of the Sumatra forearc, western Indonesia. Bulletin Geological Society of Malaysia 37, 285-299.

Müller, R.D., Roest, W.R., Royer, J.Y., Gahagan, L.M., Sclater, J.G., 1997. Digital isochrons of the world's ocean floor. Journal of Geophysical Research 102(B2), 32113214. doi: 10.1029/96JB01781.

Moore, G.F., Curray, J.R., Moore, D.G., Karig, D.E., 1980. Variations in geologic structure along the Sunda Fore Arc, northeastern Indian Ocean. In: D.E. Hayes (Ed.), The tectonic and geologic evolution of Southeast Asian seas and islands. Geophysical Monograph, vol. 23, American Geophysical Union, Washington, DC, pp. 145-160. 
Mosher, D., Austin Jr., J., Fisher, D., Gulick, S., 2008. Deformation of the northern Sumatra accretionary prism from high-resolution seismic reflection profiles and ROV observations. Marine Geology 252(3-4), 89-99. doi: 10.1016/j.margeo.2008.03.014.

Ninkovich, D., 1976. Late cenozoic clockwise rotation of Sumatra. Earth and Planetary Science Letters 29(2), 269-275. doi: 10.1016/0012-821X(76)90130-8.

Nishimura, S., Nishida, J., Yokoyama, T., Hehuwat, F., 1986. Neo-tectonics of the Strait of Sunda, Indonesia. Journal of Southeast Asian Earth Sciences 1(2), 81-91. doi: 10.1016/0743-9547(86)90023-1.

Popescu, I., M., Batist, D., Lericolais, G., Nouze, H., Poort, J., Panin, N., Versteeg, W., Gillet, H., 2006. Multiple bottom-simulating reflections in the Black Sea: potential proxies of past climate conditions. Marine Geology 227(3-4), 163-176. doi: 10.1016/j.margeo.2005.12.006.

Posewang, J., Mienert, J., 1999. The enigma of double BSRs: indicators for changes in the hydrate stability field? Geo-Marine Letters 19(1-2), 157-163. doi: $10.1007 / s 003670050103$.

Prawirodirdjo, L., Bock, Y., 2004. Instantaneous global plate motion model for 12 years of continuous GPS observations. Journal of Geophysical Research 109, B08405. doi: 10.1029/2003JB002944.

Rose, R.R., 1983. Miocene carbonate rocks of Sibolga Basin, Northwest Sumatra. Proceedings Indonesian Petroleum Association 12, 107-125.

RR0705, 2007. Cruise Report: Paleoseismologic Studies of the Sunda Subduction Zone. Oregon State University Active Tectonics Laboratory, United States; Agency for the Assessment and Application of Technology, Indonesia. http://www.activetectonics.coas.oregonstate.edu/sumatra/report/index.html. Samuel, M.A., Harbury, N.A., 1996. The Mentawai fault zone and deformation of the Sumatran Forearc in the Nias area. In: R. Hall, D. Blundell (Eds.), Tectonic Evolution of 
Southeast Asia. Special Publications, vol. 106, Geological Society, London, pp. 337351.

Schlüter, H.U., Gaedicke, C., Roeser, H.A., Schreckenberger, B., Meyer, H., Reichert, C., Djajadihardja, Y., Prexl, A., 2002. Tectonic features of the southern Sumatra-western Java forearc of Indonesia. Tectonics 21(5), 1047. doi: 10.1029/2001TC901048.

Seeber, L., Mueller, C., Fujiwara, T., Arai, K., Soh, W., Djajadihardja, Y.S., Cormier, M.H., 2007. Accretion, mass wasting, and partitioned strain over the 26 Dec 2004 Mw9.2 rupture offshore Aceh, northern Sumatra. Earth and Planetary Science Letters 263(12), 16-31. doi: 10.1016/j.epsl.2007.07.057.

Sibuet, J.C., Rangin, C., Le Pichon, X., Singh, S., Cattaneo, A., Graindorge, D., Klingelhoefer, F., Lin, J.Y., Malod, J., Maury, T., Schneider, J.L., Sultan, N., Umber, M., Yamaguchi, H., 2007. 26th December 2004 great Sumatra-Andaman earthquake: Coseismic and post-seismic motions in northern Sumatra. Earth and Planetary Science Letters 263(1-2), 88-103. doi: 10.1016/j.epsl.2007.09.005.

Sieh, K., Natawidjaja, D., 2000. Neotectonics of the Sumatran Fault, Indonesia. Journal of Geophysical Research 105(B12), 28,295-28,326. doi: 10.1029/2000JB900120.

Soh, W., 2006. Seismic and Tsunami Tectonics of 26th Dec. 2004 Sumatra-Andaman Clarified in the Urgent Study. Blue Earth Special Issue 1, 14-17.

Susilohadi, S., Gaedicke, C., Ehrhardt, A., 2005. Neogene structures and sedimentation history along the Sunda forearc basins off southwest Sumatra and southwest Java. Marine Geology 219(2-3), 133-154. doi: 10.1016/j.margeo.2005.05.001.

Tappin, D., McNeill, L., Henstock, T., Mosher, D., 2007. Mass wasting processes offshore Sumatra. In: V. Lykousis, D. Sakellariou, J. Locat (Eds.), Submarine Mass Movements and Their Consequences. Advances in Natural and Technological Hazards Research, vol. 27, Springer Netherlands, pp. 327-336. doi: 10.1007/978-1-4020-65125_34. 
van der Werff, W., 1996. Variation in forearc basin development along the Sunda Arc, Indonesia. Journal of Southeast Asian Earth Sciences 14(5), 331-349. doi: 10.1016/S0743-9547(96)00068-2.

Wessel, P., Smith, W., 1991. Free software helps map and display data. Eos, Transactions American Geophysical Union 72(41), 441. doi: 10.1029/90EO00319.

\section{Figure Captions}

\section{Figure 1:}

Bathymetric map off northern Sumatra. Lines indicate positions of seismic sections (Figs. 3-10), boxes of detailed bathymetry (Fig. 2). Land image is derived from SRTMv2 data, light bathymetric background from the GEBCO One Minute Grid. The inset shows the regional tectonic setting of the Sumatran subduction zone. IFZ = Investigator Fracture Zone. Sumatran Fault Zone (SFZ), Mentawai Fault Zone (MFZ), Batee Fault (BF), West Andaman Fault (WAF) and deformation front are based on Sieh and Natawidjaja (2000). Ages of the oceanic crust are after Müller et al. (1997) and Deplus et al. (1998) in million years. Gray arrows indicate relative plate movements based on NUVEL-1A (DeMets et al., 1994), black arrows based on CGPS (Prawirodirdjo and Bock, 2004).

Figure 2:

Detailed bathymetric maps of the study area. Letter order is from NW to SE (note different scale of maps). See Fig. 1 for location of maps and color scale.

A: Aceh Basin. The West Andaman Fault (WAF) is a mainly linear feature with subordinate faults branching off both into the forearc basin and outer arc high. 
B: Southern Aceh- and northern Tuba Basins. The Tuba Ridge connects the West Andaman Fault and Mentawai Fault Zone (MFZ) through a left-hand step-over. A rightlateral strike-slip fault cuts the outer arc high resulting in extrusion of the northern Tuba Basin.

C: Southern Tuba- and northern Simeulue Basins. The Mentawai Fault Zone developed a positive flower structure separating the basins. The Tuba Basin is tilted eastwards by uplift along a thrust fault at the western boundary.

D: Western Simeulue Basin and part of Simeulue Island. Sigmoidal shaped anticlines indicate the main line of the Mentawai Fault Zone on the eastern shelf off Simeulue Island. Normal faults with SW-NE strike are located at the crest of a semicircular uplifted area. E: Southwestern Simeulue Basin. The transition of the outer arc high to the basin is characterized by wrench-fault related anticlines.

\section{Figure 3:}

MCS profile across the central Aceh Basin. Older sediments $(A)$ are tilted westwards and the depocenter moved trenchward (B). The inset illustrates the typical expression of the West Andaman Fault (WAF) in the Aceh segment. See Fig. 1 for location of profile.

\section{Figure 4:}

MCS profile across the southern Aceh Basin. Older basin sediments $(A)$ are uplifted and deformed by the West Andaman Fault (WAF), leaving little sedimentation space for Sequence B. See Fig. 1 for location of profile.

\section{Figure 5:}

MCS profile covering the southern Aceh Basin, Tuba Ridge and northern Tuba Basin. Older sediments of the northern Tuba Basin belonged to the depocenter of the Aceh Basin 
before the formation of the Tuba Ridge. Sediment echosounder data (inset) show tear of youngest sediments due to extrusion. See Fig. 1 for location of profile.

\section{Figure 6:}

A: MCS profile from the West Andaman Fault (WAF) to the Sumatran Fault Zone (SFZ). Sediments of sequence A are deformed by an older strike-slip fault. The depocenter of the Aceh Basin moved westward over time.

B: Single-channel seismic profile located on the eastern slope of the Aceh Basin showing the non-active strike-slip fault. See Fig. 1 for location of profiles.

\section{Figure 7:}

MCS profile across the central part of the Tuba Basin perpendicular to the main axis of the basin. A thrust fault uplifting and tilting the western part of the basin is clearly imaged. Sediments are deformed by reverse faults due to tilting. See Fig. 1 for location of profile.

\section{Figure 8:}

MCS profile covering the southern Tuba- and northwestern Simeulue Basins. In between, the Mentawai Fault Zone (MFZ) developed a positive flower structure. The Tuba Basin is sediment starved and more than $300 \mathrm{~m}$ deeper than the Simeulue Basin. An eastward inclined buildup-structure indicates uplift along a thrust fault tilting the Tuba Basin and resulting in compression and reverse faulting. See Fig. 1 for location of profile.

Figure 9:

MCS profile across the western part of the Simeulue Basin parallel to the main axis of the basin. The Mentawai Fault Zone (MFZ) is developed as a positive flower structure. An anticline with normal faulting at the crest indicates recent uplift (inset with sediment 
775 echosounder data). Note the "double" BSR in the uplifted region. See Fig. 1 for location of 776 profile.

778 Figure 10:

779 MCS profile covering the southwestern part of the Simeulue Basin and adjacent outer arc 780 high. Alternating intensity of wrench faulting is documented by interfingering sedimentary 781 packages caused by changing direction of sediment supply. The inset with sediment 782 echosounder recordings illustrates recent uplift of youngest sediments. The solid line 783 marks the initiation of the easternmost wrench fault. See Fig. 1 for location of profile.

Figure 11:

Tectonic structures in the working area. WAF = West Andaman Fault; SFZ = Sumatran

Fault Zone; BF = Batee Fault; MFZ = Mentawai Fault Zone; TR = Tuba Ridge. The northern branch of the Mentawai Fault Zone jumped westwards to the position of the West Andaman Fault. A transpressional step-over formed the Tuba Ridge. A right-lateral strikeslip fault runs from the conjunction of the West Andaman Fault and Tuba Ridge in SSWdirection crossing the outer arc high, resulting in extrusion of the Tuba Basin which is tilted eastwards by uplift along a thrust fault. 
Figure 01

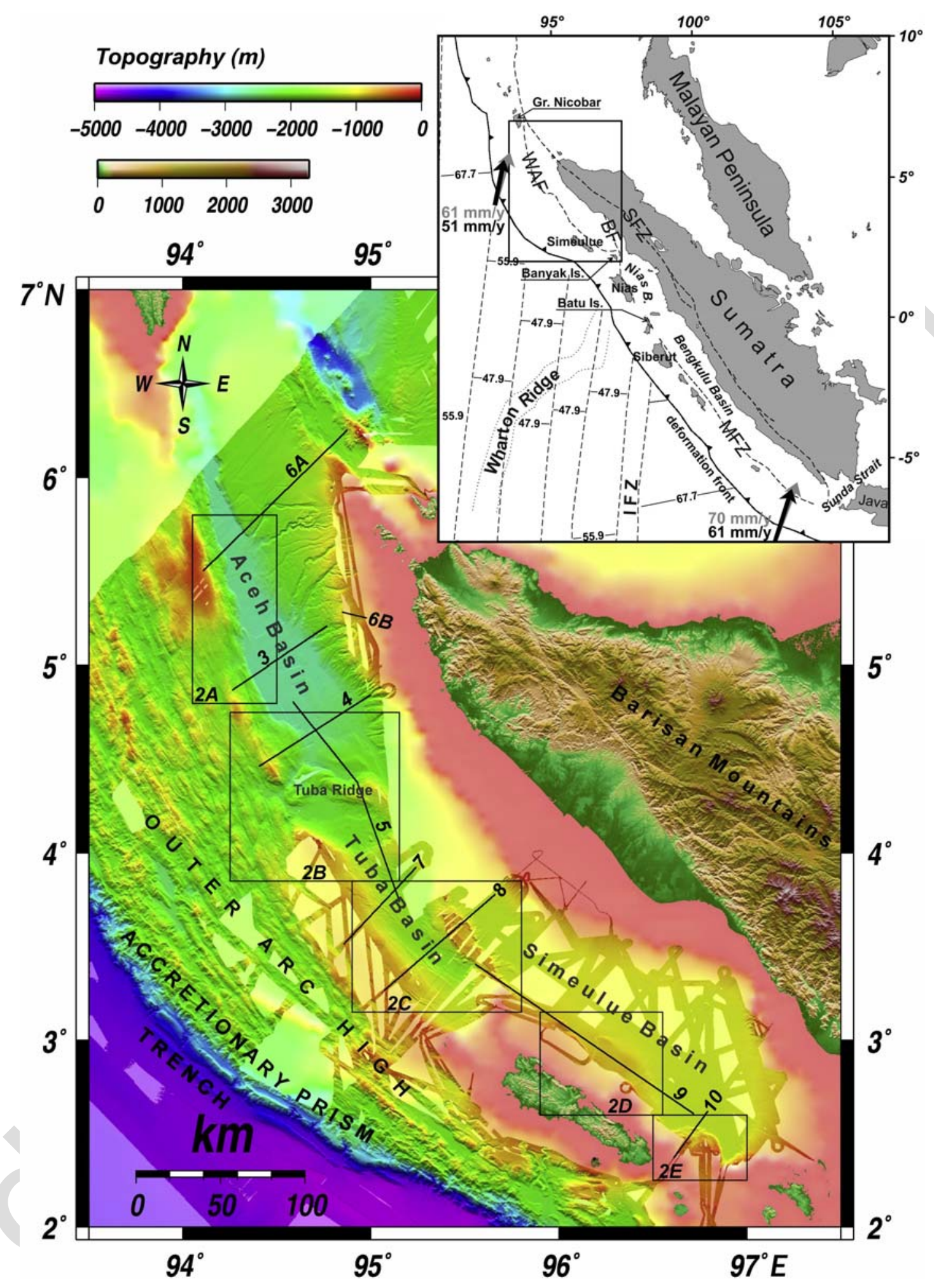


Figure 02

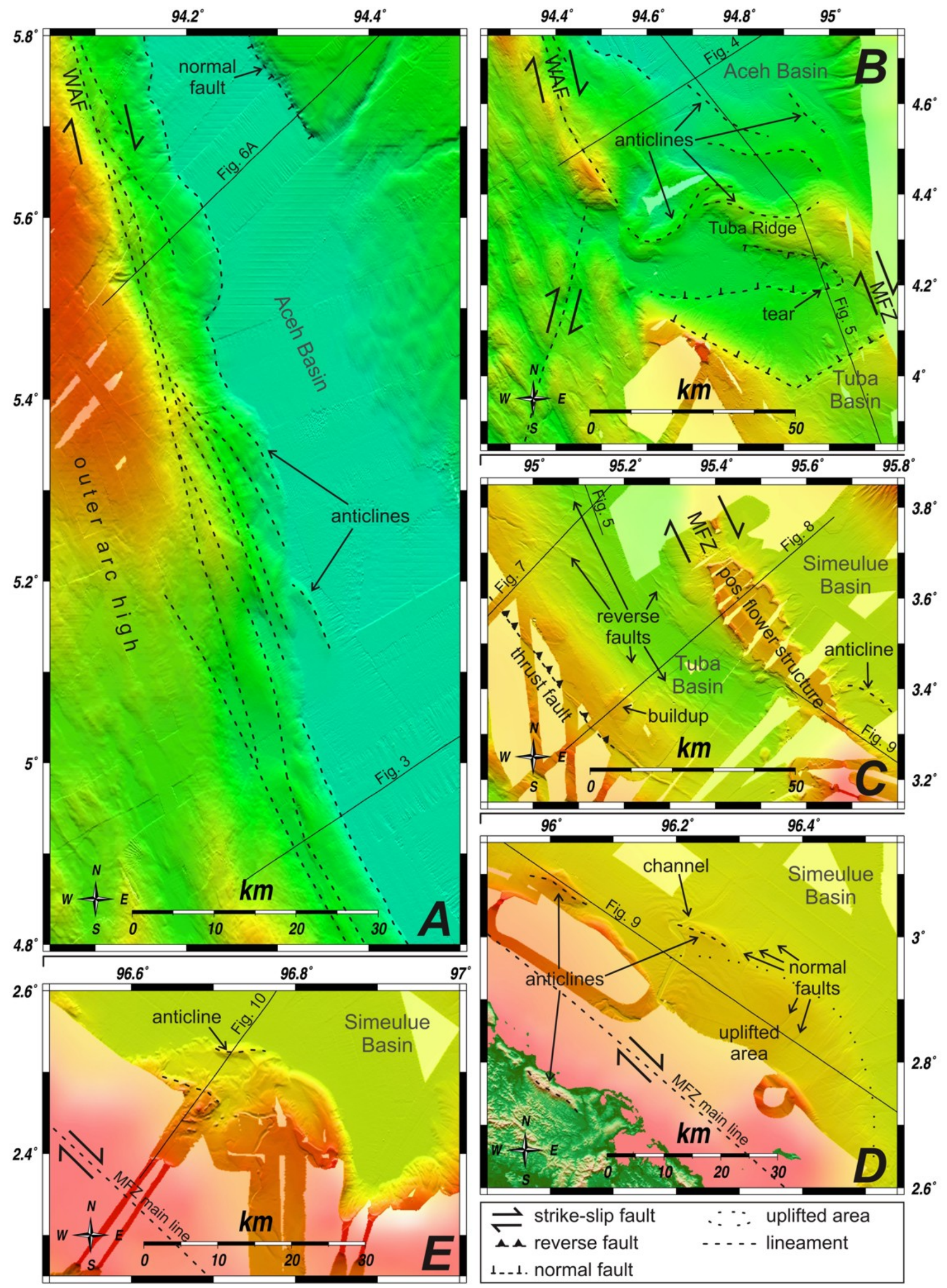


Figure 03
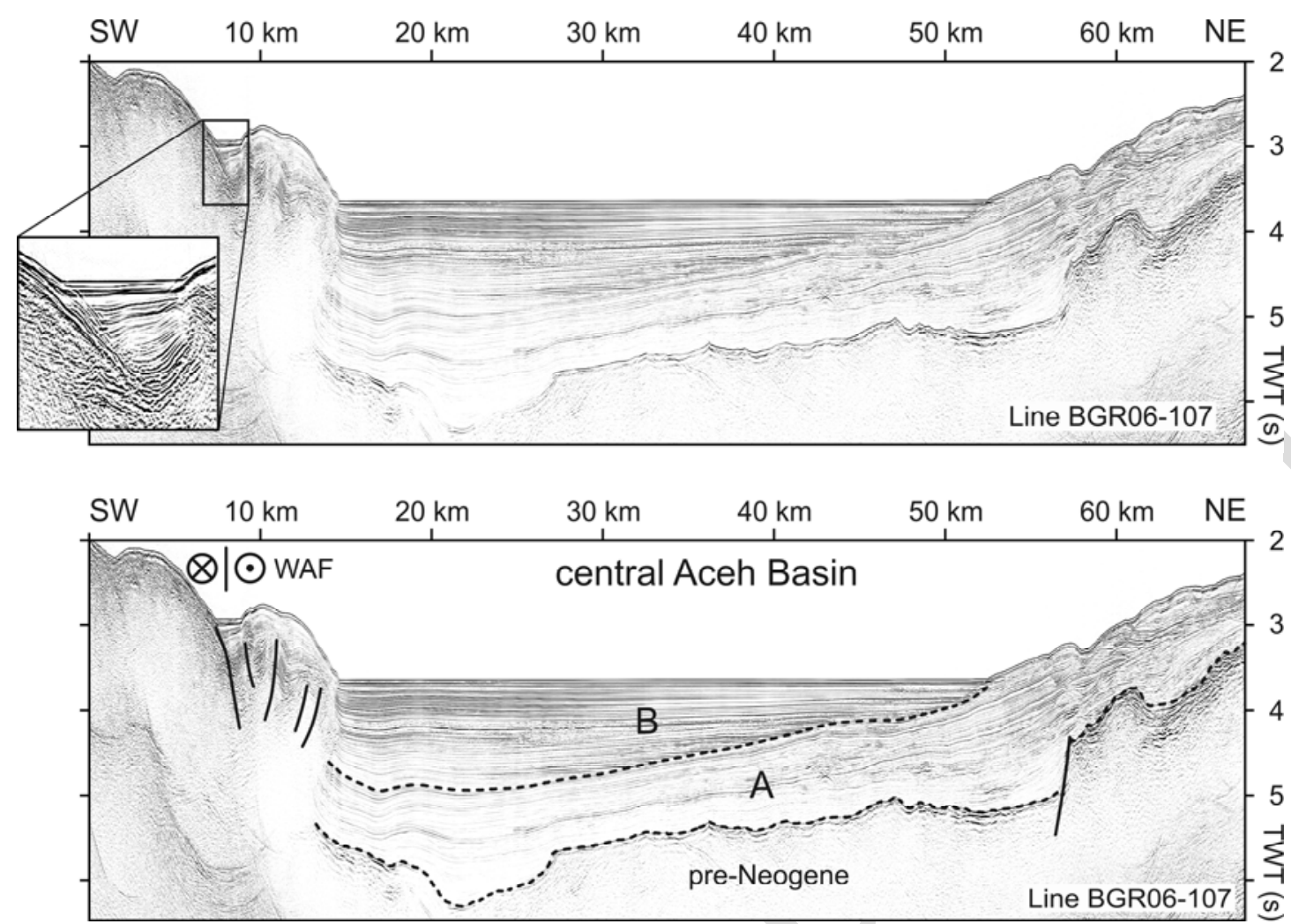
Figure 04

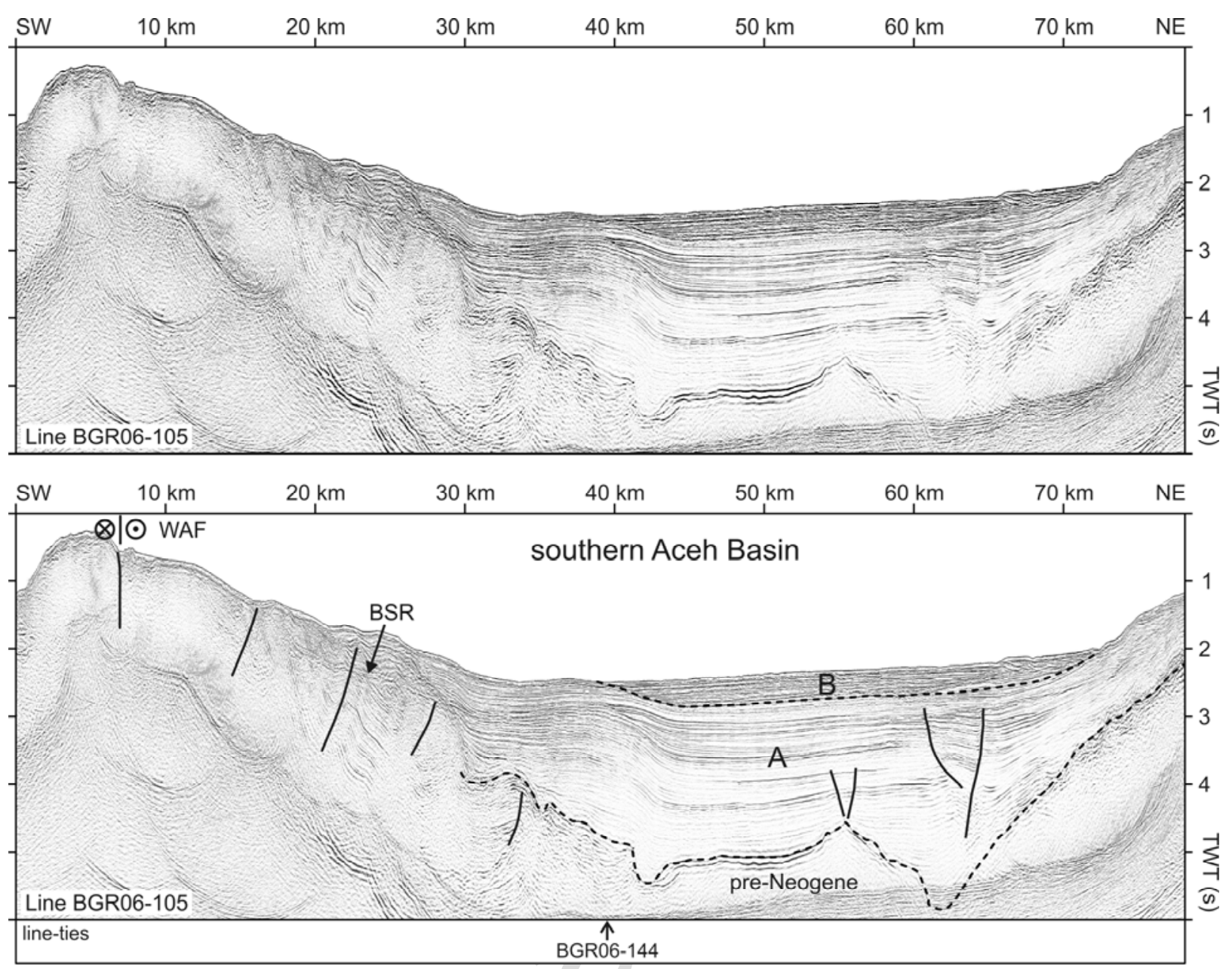


Figure 05
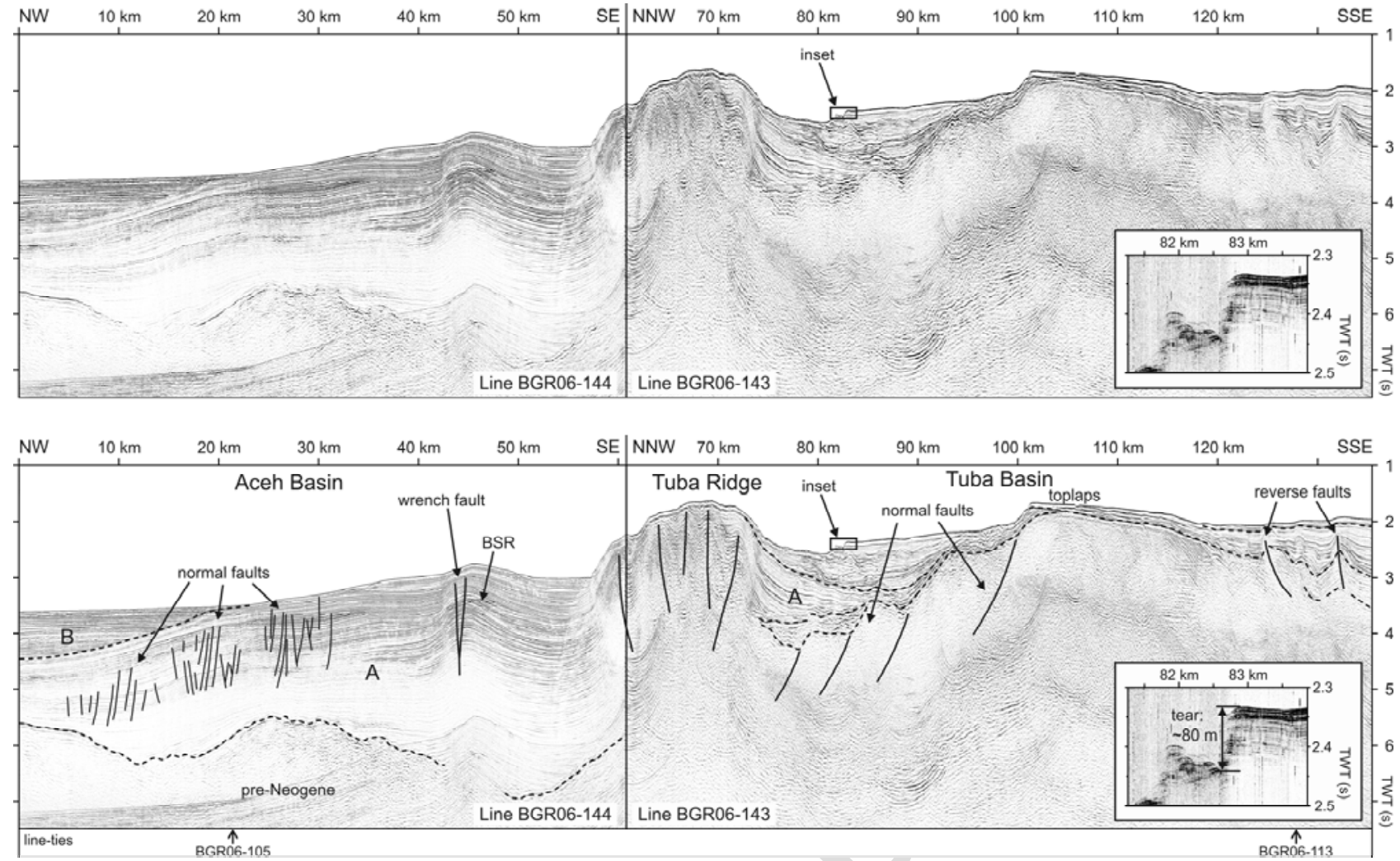
Figure 06

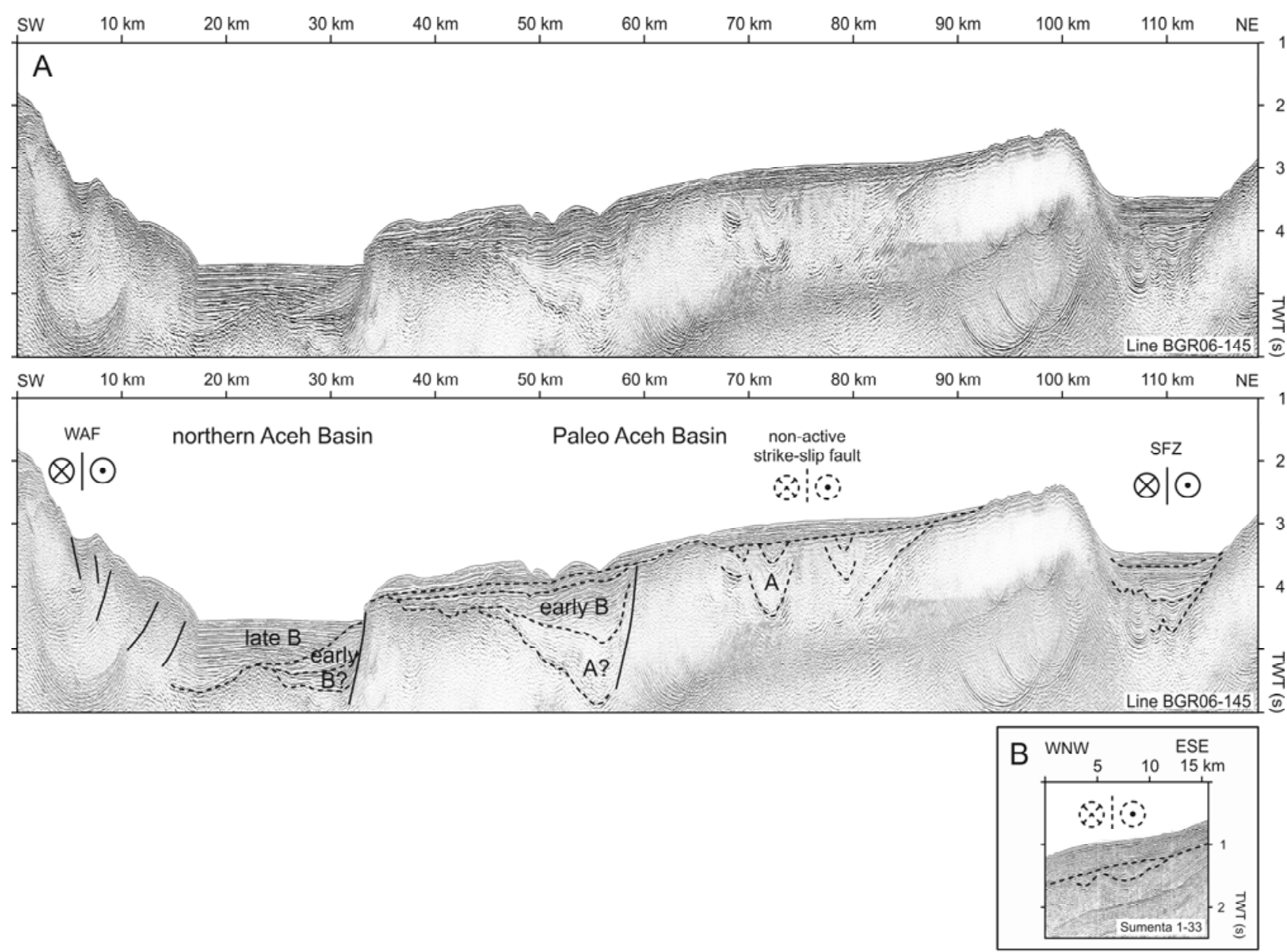


Figure 07
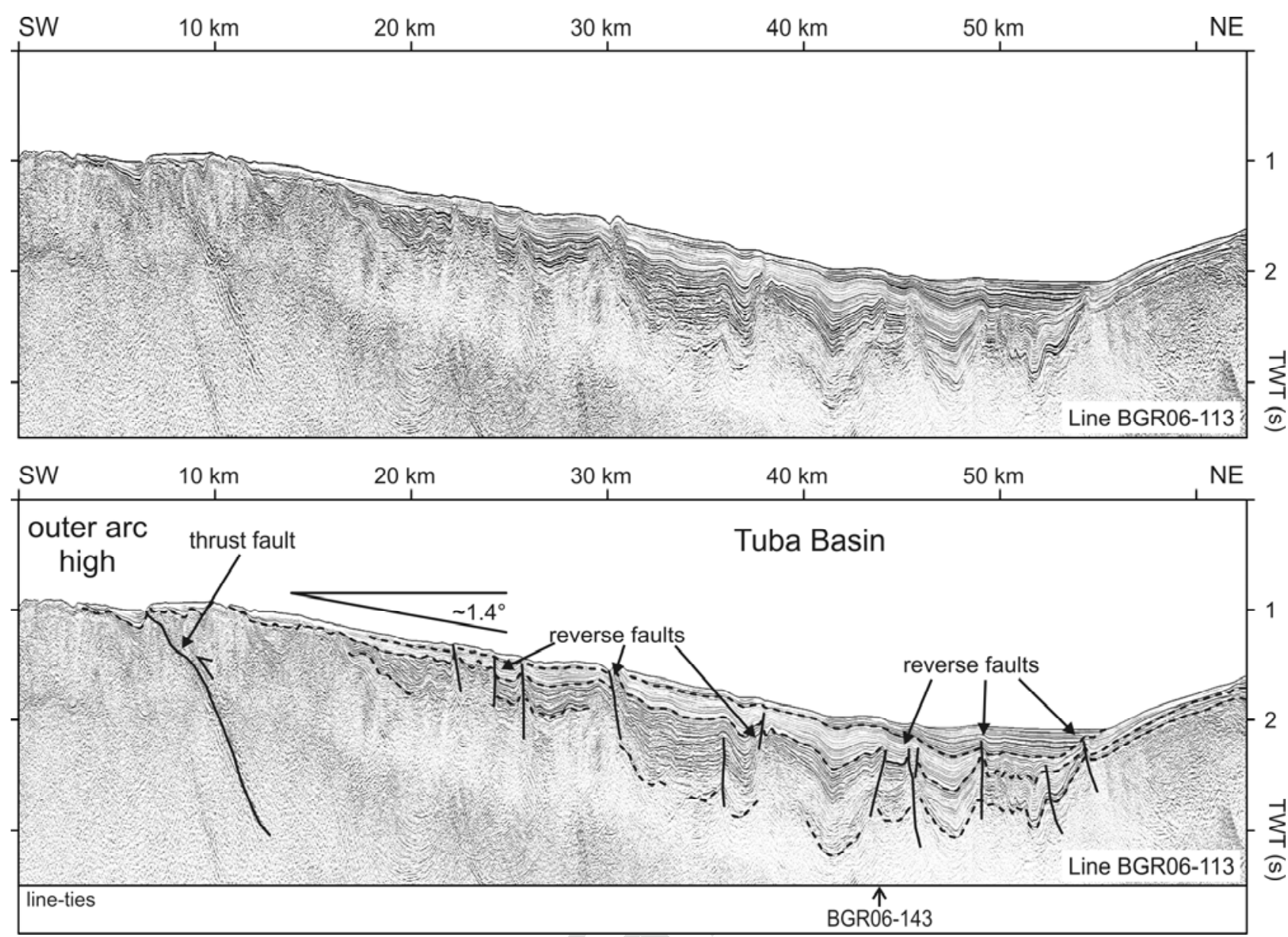
Figure 08
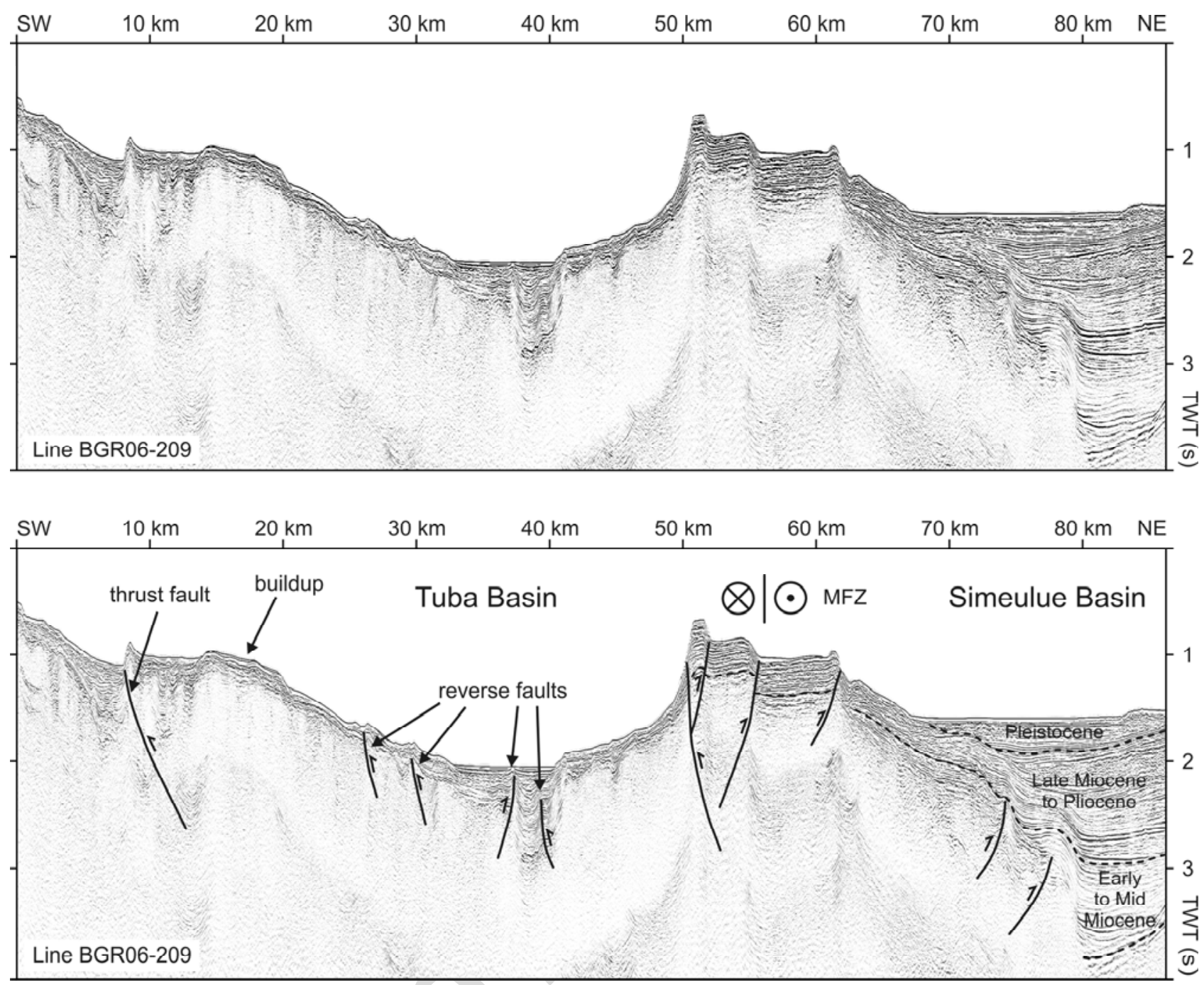
Figure 09

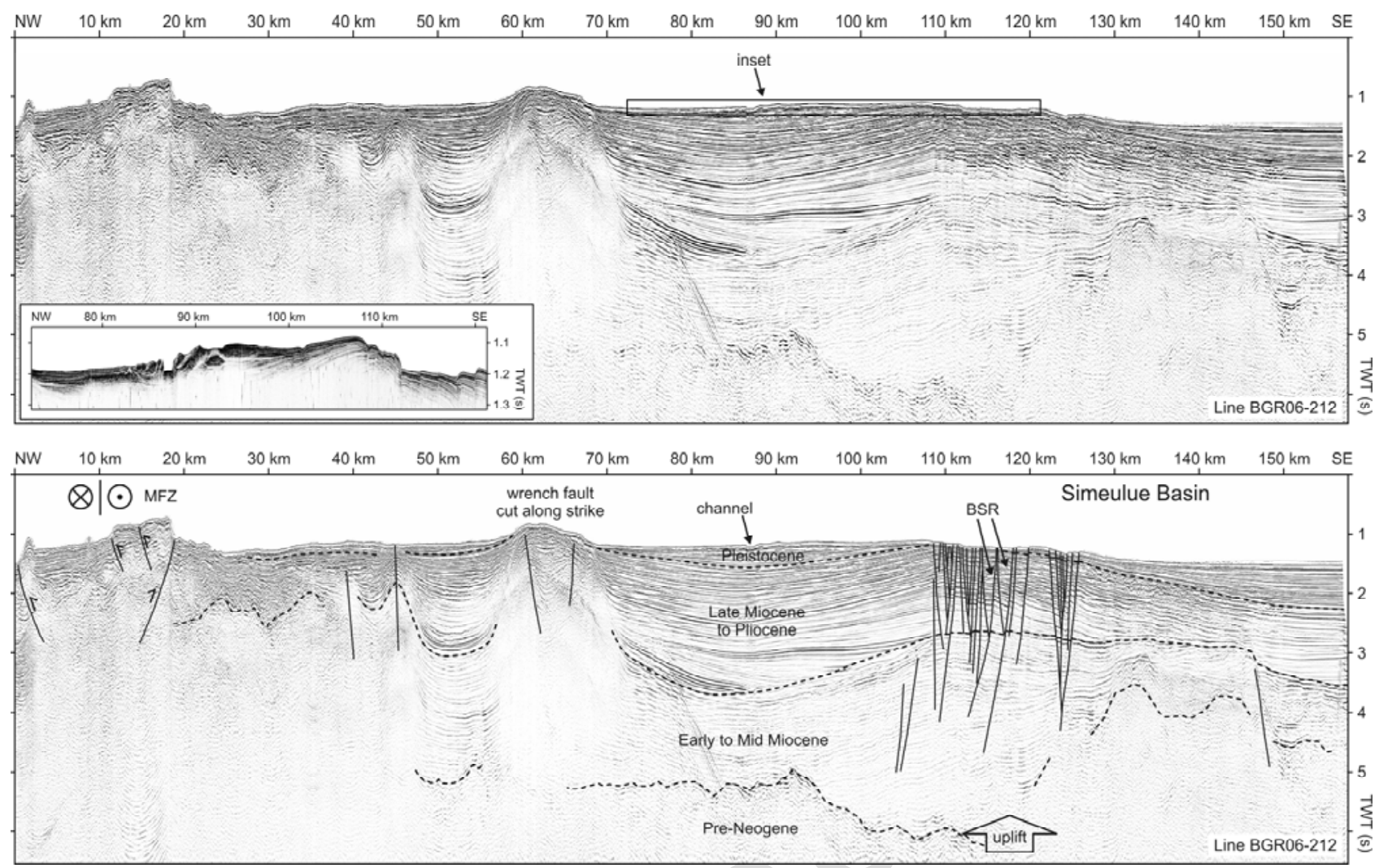


Figure 10

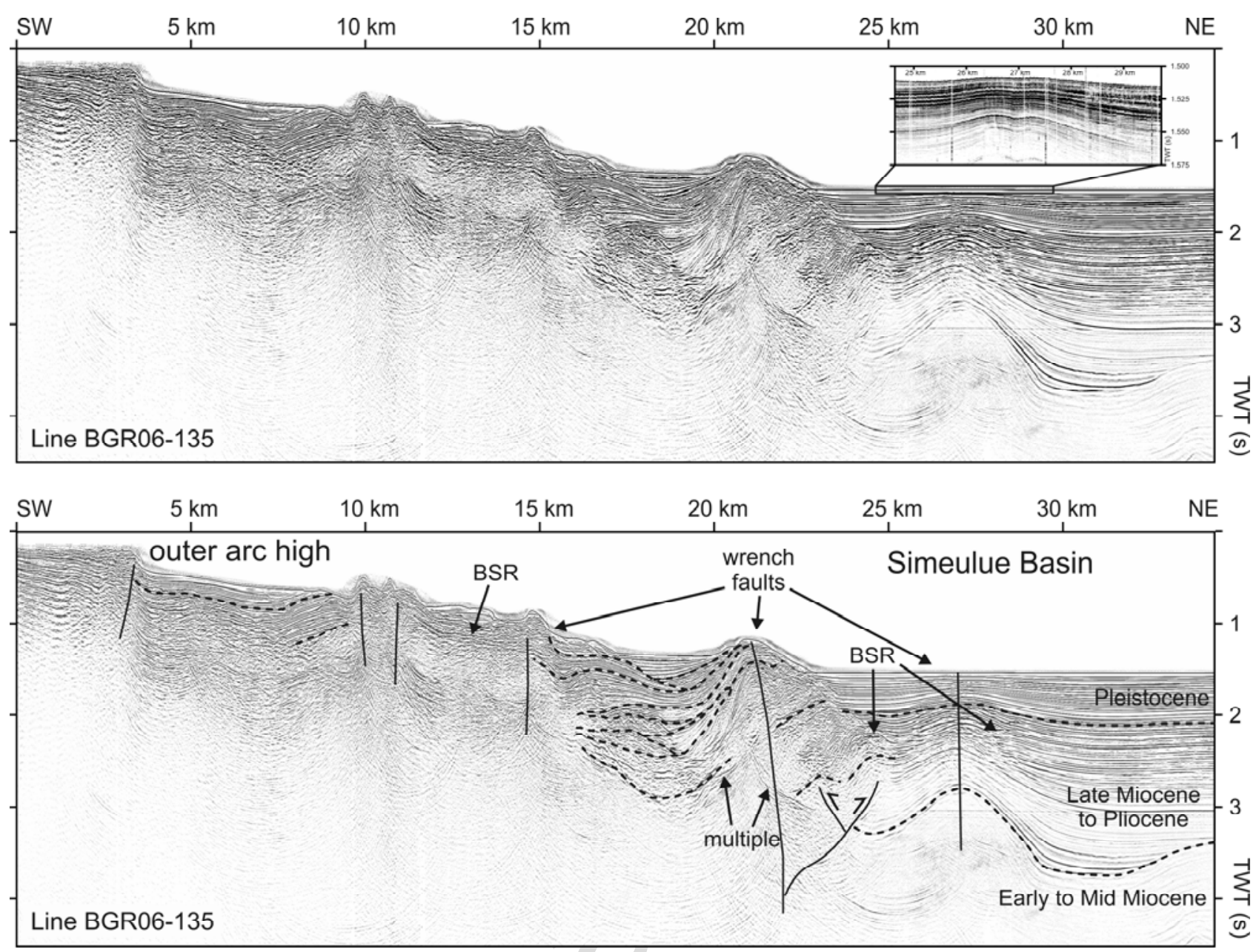


Figure 11

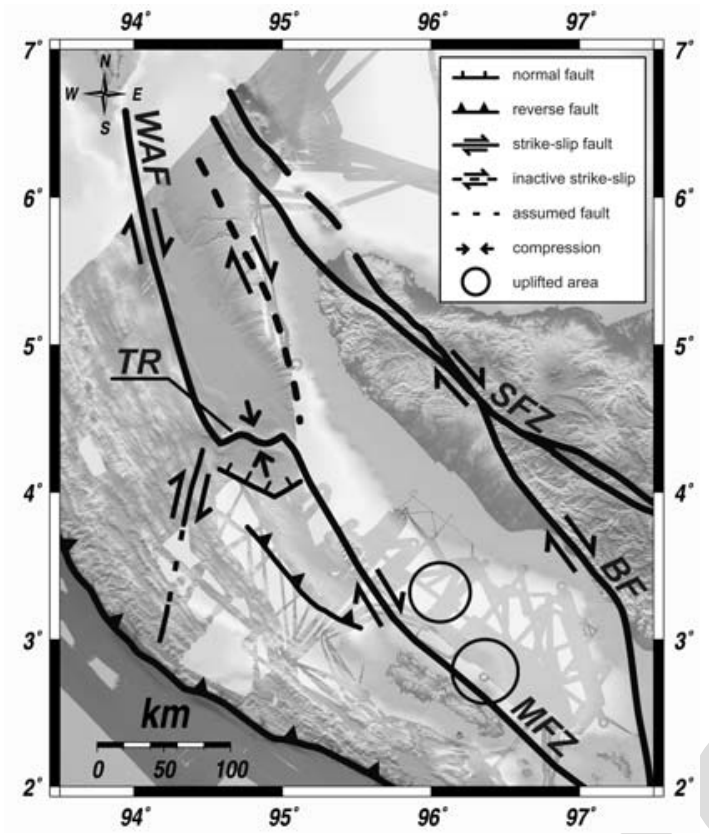

